Jurnal Fokus Manajemen Bisnis
Vol. 11, No.1, Maret 2021, pp.1-21
https://doi.org/10.12928//fokus.v11i1.3194
http://journal2.uad.ac.id/index.php/fokus
$\begin{aligned} & \text { Universitas } \\ & \text { Ahmad Dahlan }\end{aligned}$

\title{
PENGARUH BUDAYA ORGANISASI TERHADAP ORGANIZATIONAL CITIZENSHIP BEHAVIOR DENGAN KOMITMEN ORGANISASI SEBAGAI VARIABEL MEDIASI (STUDI KASUS PADA BADAN KEUANGAN DAN ASET DAERAH KABUPATEN SLEMAN)
}

\author{
Andira Ramadha Arundita1, Didik Subiyanto ${ }^{2,}{ }^{*}$, Ignatius Soni Kurniawan ${ }^{3}$ \\ Universitas Sarjanawiyata Tamansiswa \\ didiks@ustjogja.ac.id \\ *Didik Subiyanto
}

Article history

Received 2020-12-09

Revised 2021-03-20

Accepted 2021-03-21

Keywords

Organizational Culture

Organizational Citizenship Behavior

Organizational Commitment
The purpose of this study was conducted to determine the effect of the relationship between organizational culture and organizational citizenship behavior (OCB) with organizational commitment as a mediating variable. This research was conducted in the Regional Financial Institutions and Assets of Sleman Regency. The sample in this study were all employees of the Regional Financial Institutions and Assets of Sleman Regency. Data collection by distributing questionnaires using a Likert scale to measure indicators. The technique used in this research is descriptive analysis. The results of this study indicate that organizational culture has a positive and significant effect on organizational commitment, organizational culture has a positive and significant effect on organizational citizenship behavior (OCB), organizational commitment has a positive and significant effect on organizational citizenship behavior (OCB) and organizational commitment acts as mediation affect organizational culture and organizational citizenship behavior (OCB).

This is an open-access article under the CC-BY-SA license.

\section{Pendahuluan}

Sumber daya manusia adalah salah satu faktor yang sangat penting bahkan tidak dapat dilepaskan dari sebuah organisasi. Perkembangan ilmu terkait dengan sumber daya manusia yang semakin dinamis memandang bahwa karyawan bukan hanya sebagai sumber daya belaka, tetapi juga lebih berupa modal atau aset bagi organisasi. Perkembangan tersebut menyebabkan munculnya istilah baru di luar sumber daya manusia, yaitu modal intelektual yang bersifat kolektif berupa kompetensi, pengetahuan, dan keterampilan yang dimiliki oleh seseorang (Becker, 2002). Sumber daya manusia dimata perusahaan bukan hanya sekadar aset utama, tetapi juga sebagai aset yang bernilai, dapat dilipatgandakan, dikembangkan dan bukan sebaliknya sebagai liability (beban).

Pada hakikatnya, sumber daya berupa manusia yang dipekerjakan di sebuah organisasi sebagai penggerak, pemikir, dan perencana untuk mencapai tujuan organisasi itu. Sumber daya manusia merupakan faktor yang sangat sentral dalam organisasi, apapun bentuk dan tujuannya, organisasi dibuat berdasarkan berbagai visi untuk kepentingan manusia (Kalangi, 2015). Pentingnya sumber daya manusia dalam suatu organisasi menuntut organisasi mendapatkan karyawan yang berkualitas dan produktif. 
Fenomena yang terdapat di lapangan, pada era globalisasi ini setiap perusahaan seharusnya memberikan perhatian yang besar terhadap lingkungan eksternal dan internal organisasi, agar dapat mengetahui faktor-faktor yang mempengaruhi perubahan dan kesuksesan dalam bersaing. Para pemimpin organisasi harus mengaitkan pelaksanaan manajemen sumber daya manusia dengan strategi organisasi untuk meningkatkan kinerja, serta mengembangkan budaya organisasi yang akan mendukung penerapan inovasi dan fleksibilitas (Sisca et al., 2021). Dengan demikian, pemahaman segenap sumber daya manusia tentang fungsi, peran, keterampilan, aktivitas, dan pendekatan dalam menjalankan manajemen yang mempunyai arti penting untuk mencapai tujuan organisasi yang selalu berubah.

Salah satu alasan yang membuat sumber daya manusia memiliki suatu keunikan tersendiri di samping faktor-faktor lainnya sebagai penunjang keberlangsungan sebuah perusahaan, karena manusia memiliki akal, perasaan, keinginan, kemampuan, keterampilan, pengetahuan, dorongan, dan karya yang berbeda-beda antara satu dengan lainnya (Maulana, 2015). Bagi sebuah perusahaan, perbedaan-perbedaan tersebut selayaknya dapat diorganisir agar mampu menciptakan sebuah kerjasama tim dalam melewati perubahan pada era globalisasi ini. Proses perubahan perusahaan tentunya akan mempengaruhi pada keadaan lingkungan internal perusahaan (Yulianti, 2014). Salah satu nilai terpenting yang harus senantiasa dipertahankan oleh setiap karyawan untuk menghadapi hal ini adalah beradaptasi dengan perubahan yang terjadi dan dapat menjunjung tinggi kerjasama tim yang baik, karena setiap individu memiliki status sosial yang berbeda-beda, baik itu keyakinan maupun sikap dari karyawan. Perbedaaan tersebut yang menjadikan tantangan bagi perusahaan dalam menghadapi status sosial yang dimiliki karyawan.

Organizational Citizenship Behavior (OCB) menjadi salah satu bukti adanya kerjasama tim yang solid di dalam perusahaan atau organisasi. OCB merupakan perilaku individu yang bebas, yang tidak secara langsung atau eksplisit diakui oleh sistem pemberian penghargaan dan dalam mempromosikan fungsi efektif organisasi. Dengan kata lain OCB adalah perilaku karyawan yang melebihi peran yang diwajibkan, yang tidak secara langsung diakui oleh sistem reward formal merupakan perilaku pilihan yang tidak menjadi bagian dari kewajiban kerja formal seorang karyawan, namun mendukung berfungsinya organisasi tersebut secara efektif (Lubis, 2015).

Dalam dunia kerja yang semakin kompleks dengan tugas-tugas yang semakin banyak dilakukan dalam tim dan fleksibilitas merupakan suatu hal yang penting, sehingga organisasi memerlukan karyawan yang dapat melakukan perilaku OCB, seperti membuat pernyataan konstruktif tentang kelompok kerja mereka dan organisasi, membantu yang lain dalam timnya, menghindari konflik, menghormati peraturan yang telah dibuat. Adanya OCB dapat mengurangi terjadinya perselisihan dan meningkatkan efisiensi pekerjaan. Dengan demikian secara tidak langsung perilaku tersebut dapat menumbuhkan hasil yang positif bagi perusahaan atau organisasi, baik untuk tujuan perusahaan itu sendiri maupun untuk kehidupan sosial dalam perusahaan.

Emami et al., (2012) mengatakan bahwa terdapat beberapa variabel yang mempengaruhi perilaku OCB karyawan, diantaranya adalah kejelasan peraturan, kepemimpinan, komitmen organisasi, keadilan organisasi, dan budaya organisasi. Selanjutnya Emami et al., (2012) juga mengungkapkan bahwa OCB akan berhubungan dengan lima paramater dalam penyelenggaraan organisasi yaitu mengurangi turnover, mengurangi tingkat absensi, kepuasan, dan loyalitas dari karyawan. Hal ini berarti OCB merupakan suatu bagian dari perilaku individu dalam hal ini karyawan yang sangat penting dalam melaksanakan setiap tugasnya dan kewajiban karyawan selanjutnya akan bermuara pada keberhasilan perusahaan. Karyawan yang memiliki perilaku OCB menjadi hal yang secara esensial menguntungkan perusahaan karena aktivitas yang dilakukan melalui OCB mampu menjadi sumber daya tambahan bagi perusahaan (Lee et al.,2017). 
Globalisasi telah memberikan perubahan bagi setiap organisasi untuk melaksanakan perubahan pada sisi internalnya. Sisi internal yang meliputi pengelolaan sumber daya manusia, kebijakan organisasi, dan keadaan situasional pada sebuah perusahaan. Salah satu bagian yang mutlak mengikuti perubahan dalam sebuah perusahaan adalah komitmen organisasi. Amir (2019) mendefinisikan komitmen organisasi adalah tingkatan seorang karyawan dalam mengaitkan dirinya ke organisasi tertentu dan sasaran-sasarannya, dan berharap dapat mempertahankan keanggotaan dalam organisasi tersebut. Komitmen organisasi menjadi salah satu anteseden yang kuat dari OCB (Khan dan Rashid, 2012). Komitmen organisasi dapat menjadi dorongan psikologis dalam menjalankan peran dan fungsi karyawan dalam organisasinya untuk mencapai tujuan yang diharapkan (Sari dan Dwirandra, 2019). Seseorang yang memiliki komitmen organisasi yang tinggi, maka ia akan semakin sering menunjukkan perilaku-perilaku positif dan bahkan melakukan sesuatu yang berada di luar deskripsi formal pekerjaannya.

Selain OCB dan komitmen organisasi yang menjadi fokus dalam perubahan yang ada di dalam organisasi yaitu dengan adanya budaya organisasi sebagai bentuk dalam menciptakan perilaku OCB dan komitmen organisasi sebagai mediasi di dalam perusahan. Pada era yang semakin kompetitif, budaya organisasi berkembang sesuai perkembangan lingkungan (Wibowo, 2012). Budaya organisasi memiliki tujuan untuk mengubah sikap dan perilaku sumber daya manusia yang ada, agar lebih meningkatkan produktivitas kerja guna menghadapi berbagai tantangan dimasa yang akan datang. Di sisi lain, budaya organisasi memiliki dampak yang kuat pada perilaku karyawan yang diikuti dengan efektivitas organisasi dan akan memudahkan manajer dalam memahami organisasi dimana mereka bekerja tidak hanya untuk perumusan kebijakan dan prosedur, tetapi untuk memahami perilaku manusia dan pemanfaatan sumber daya manusia mereka dengan cara yang baik (Khan dan Rashid, 2012). Fernandes (2018) mengungkapkan bahwa budaya organisasi memberikan dampak yang positif terhadap peningkatan motivasi karyawan. Oleh karena itu, tentunya perusahaan perlu membangun budaya organisasi birokrasi dimana kesepakatan bersama tentang nilai-nilai bersama dalam kehidupan organisasi dan mengikat semua orang dalam organisasi yang bersangkutan. Budaya organisasi birokrasi akan menentukan apa yang boleh dan tidak boleh dilakukan oleh para anggota organisasi, menentukan batas-batas normatif perilaku anggota organisasi, menentukan sifat dan bentuk-bentuk pengendalian, pengawasan organisasi, dan menentukan gaya manajerial yang dapat diterima oleh para anggota organisasi serta menentukan cara-cara kerja yang tepat.

OCB dan komitmen organisasi mampu menjadi faktor munculnya budaya organisasi diantara karyawan yang pada akhirnya akan mempengaruhi karyawan untuk menunjukkan nilai-nilai dan sikap positif di luar deskripsi pekerjaannya dan saling memunculkan sikap tolong menolong antara karyawan satu dengan yang lainnya. Dengan adanya sikap positif yang dimunculkan perusahaan untuk karyawan dapat menciptakan keunggulan bersaing yang baik di dalam organisasi.

Penelitian ini mengambil sampel pada Badan Keuangan dan Aset Daerah (BKAD) Kabupaten Sleman. BKAD Sleman adalah sebuah instansi pemerintahan dengan tugas utama melaksanakan pengelolaan keuangan dan aset daerah. Sedangkan fungsi dari BKAD Kabupaten Sleman yaitu sebagai perumusan kebijakan teknis bidang keuangan dan aset daerah, pelaksanaan tugas bidang keuangan dan aset daerah, penyelenggaraan pelayanan bidang keuangan dan aset daerah, pembinaan keuangan dan aset daerah, pengkoordinasian keuangan dan aset daerah, dan pelaksanaan tugas lain yang diberikan oleh Bupati sesuai dengan tugas dan fungsinya. 


\section{Review Literatur dan Hipotesis}

\subsection{Landasan Teori}

\subsubsection{Organizational Citizenship Behavior (OCB)}

Pratiwi dan Suharnomo (2013) menjelaskan OCB merupakan bentuk perilaku yang merupakan pilihan dan inisiatif individual, tidak berkaitan dengan sistem reward formal organisasi, tetapi secara agregat meningkatkan efektivitas organisasi. Hal tersebut dapat diartikan bahwa karyawan yang memiliki OCB lebih kepada kesadaran ataupun kerelaan pribadi untuk berperilaku sosial dan bekerja melebihi apa yang diharapkan sesama karyawan maupun terhadap perusahaan.

Pratiwi dan Suharnomo (2013) mengatakan bahwa kebanyakan dari perilaku yang mencerminkan OCB tidak mudah diatur dengan skema insentif individu, karena perilaku seperti itu sering kabur dan sulit untuk mengukurnya. Perbedaan yang mendasar antara perilaku in-role dan extra-role terletak pada hasil yang diperoleh atau penghargaan. Perilaku in-role biasanya dihubungkan dengan penghargaan dan hukuman (sanksi), sedangkan perilaku extra-role tidak dihubungkan dengan penghargaan yang akan diterima. Oleh karena itu, OCB merupakan perilaku yang berkaitan dengan pilihan pribadi, apabila seseorang karyawannya menunjukkan perilaku tersebut, maka ia akan merasakan kepuasan di dalam dirinya sendiri, dan apabila tidak menunjukkan perilaku tersebut tidak akan menyebabkan hukuman dalam organisasi.

\subsubsection{Komitmen Organisasi}

Dewi dan Suwandana (2016) menyatakan komitmen organisasi adalah sikap yang mencerminkan sejauh mana seorang individu mengenal dan terikat pada organisasinya. Komitmen organisasi dibangun melalui suatu proses identifikasi dimana seseorang melakukan sesuatu dari suatu ide sebagai pengembangan dirinya. Seorang karyawan yang memiliki komitmen, akan tetap bersama organisasinya dalam kondisi menyenangkan atau tidak yang dialami oleh organisasinya.

Budiono (2016) menyebutkan komitmen karyawan pada organisasi sebagai ikatan kejiwaan individu terhadap organisasi yang mencakup keterlibatan kerja, kesetiaan, dan perasaan percaya terhadap nilai-nilai organisasi. Menurut Budiono (2016) bahwa suatu bentuk komitmen yang muncul bukan hanya bersifat loyalitas yang pasif, tetapi juga melibatkan hubungan yang aktif dengan organisasi kerja yang memiliki tujuan memberikan segala urusan demi keberhasilan organisasi yang bersangkutan.

\subsubsection{Budaya Organisasi}

Menurut Amir (2019) budaya organisasi sebagai nilai-nilai dominan yang disebarluaskan dalam organisasi yang dijadikan filosofi kerja karyawan yang menjadi panduan bagi kebijakan organisasi dalam mengelola karyawan. Selain itu, menurut Budiono (2016) budaya organisasi merupakan norma-norma dan nilai-nilai yang mengarahkan perilaku anggota organisasi. Setiap anggota akan berperilaku sesuai dengan budaya yang berlaku agar diterima oleh lingkungannya. Dari sudut pandang karyawan, budaya organisasi memberikan pedoman bagi karyawan atas segala sesuatu yang penting untuk dilakukan dalam perusahaan. Dari berbagai pengertian yang dijelaskan di atas, maka dapat disimpulkan bahwa budaya organisasi merupakan suatu komponen penting yang ada di dalam sebuah perusahan, karena merupakan suatu nilai yang akan menentukan perilaku dari seluruh karyawan yang berada di dalam perusahaan dan merupakan suatu komponen yang dapat membedakan antara suatu organisasi dengan organisasi yang lainnya. Perusahaan yang memiliki budaya organisasi yang efektif cenderung mampu menciptakan peningkatan produktivitas, 
memiliki tingkat keterlibatan karyawan yang tinggi, dan menghasilkan peningkatan manfaat yang besar bagi organisasi (Tannady dan Sitorus, 2017).

\subsection{Hipotesis}

\subsubsection{Pengaruh Positif Budaya Organisasi terhadap Komitmen Organisasi}

Dengan adanya budaya organisasi akan menciptakan sebuah nilai, norma, dan perilaku yang akan dipegang teguh oleh para karyawan, dimana perusahaan tersebut akan membedakan antara perusahaan satu dengan perusahaan yang lainnya. Budaya organisasi memiliki dampak yang kuat pada perilaku karyawan yang diikuti dengan efektivitas organisasi yang akan memudahkan manajer dalam memahami organisasinya. Seorang karyawan yang bekerja dengan memegang nilai dari budaya organisasi akan dapat memunculkan komitmen organisasi. Komitmen organisasi itu sendiri perilaku yang ditunjukkan dalam bentuk loyalitas, serta dapat menerima tujuan dan nilai-nilai organisasi untuk mencapai tujuan suatu perusahaan.

Penelitian yang dilakukan oleh Sari (2013), Sumanto dan Hermaningsih (2016), Fasisca dan Fahmy (2018) menunjukkan bahwa budaya organisasi berpengaruh positif terhadap komitmen organisasi, dimana terdapat dimensi yang memiliki korelasi paling kuat terhadap komitmen afektif. Dalam penelitian tersebut dijelaskan bahwa nilai budaya organisasi berpengaruh positif terhadap komitmen karyawan yang pada akhirnya mengarah pada keberhasilan suatu organisasi. Berdasarkan uraian di atas, maka dapat dirumuskan hipotesis sebagai berikut:

$\mathrm{H}_{1}$ : Terdapat Pengaruh Positif Budaya Organisasi terhadap Komitmen Organisasi.

\subsubsection{Pengaruh Positif Budaya Organisasi terhadap Organizational Citizenship Behavior (OCB)}

Budaya organisasi merupakan elemen penting yang akan menentukan perilaku karyawan di dalam perusahaan. Faktor budaya organisasi dapat memicu terjadinya OCB. Karyawan yang memiliki budaya organisasi yang kuat akan mendorong terbentuknya OCB yang baik, yaitu perilaku yang terbentuk di luar job deskripsinya. Tetapi sebaliknya, jika karyawan memiliki pemahaman yang lemah tentang budaya organisasi, maka cenderung sulit terbentuknya OCB dalam perusahaan. Sedangkan untuk faktor lain yang dapat menimbulkan OCB diantaranya lingkungan kerja, iklim kerja, reward sebagai motivasi, dan adanya hubungan yang baik antara atasan dan bawahan.

Berdasarkan penelitian yang dilakukan oleh Sari dan Hajriani (2015), Rosyada dan Rahadjo (2016), Fasisca dan Fahmy (2018) menunjukkan hasil bahwa budaya organisasi berpengaruh positif terhadap OCB. Dalam penelitian tersebut dikatakan bahwa budaya organisasi dapat membentuk perilaku OCB diantara karyawan. Karyawan yang memiliki kecenderungan untuk melakukan perilaku OCB, tetapi apabila budaya yang diterapkan pada organisasi tidak siap untuk dilakukan, maka akan membuat upaya karyawan akan sia-sia. Berdasarkan uraian di atas, maka dapat dirumuskan hipotesis sebagai berikut:

$\mathrm{H}_{2}$ : Terdapat Pengaruh Positif Budaya Organisasi terhadap Organizational Citizenship Behavior (OCB).

\subsubsection{Pengaruh Positif Komitmen Organisasi terhadap Organizational Citizenship Behavior (OCB)}

Komitmen organisasi merupakan salah satu faktor penting dalam mewujudkan OCB yaitu sebagai pendorong terciptanya perilaku OCB dalam organisasi. Komitmen organisasi merupakan keyakinan yang kuat dan penerimaan pada tujuan organisasi dan nilai-nilai, kemauan untuk mengerahkan usaha yang cukup atas nama organisasi, dan 
keinginan yang pasti untuk mempertahakan keanggotaan organisasi.

Prasasti dan Yuniawan (2017) menyebutkan bahwa dalam penelitiannya menjelaskan terdapat tiga komponen dari komitmen organisasional, yang terdiri dari komitmen afektif, komitmen berkelanjutan, dan komitmen normatif yang memiliki hubungan yang positif terhadap OCB. Namun dari ketiga komponen komitmen organisasi, hanya komitmen normatif yang memiliki hubungan positif terhadap OCB. Pengaruh positif komitmen organisasi terhadap OCB juga dibuktikan dalam penelitian Kurniawan (2015), Rosyada dan Rahadjo (2016), Wombacher dan Felfe (2017). Lubis (2015) mengatakan bahwa semua dimensi OCB secara positif dipengaruhi oleh komitmen organisasi dan iklim organisasi. Berdasarkan uraian di atas, maka dapat dirumuskan hipotesis sebagai berikut:

\section{$\mathrm{H}_{3}$ : Terdapat Pengaruh Positif Komitmen Organisasi terhadap Organizational Citizenship Behavior (OCB).}

\subsubsection{Peran Mediasi Komitmen Organisasi pada Pengaruh Positif Budaya Organisasi terhadap Organizational Citizenship Behavior}

Komitmen organisasi sangat penting bagi perusahaan atau organisasi agar mampu memahami faktor yang dapat meningkatkan komitmen organisasi di dalam perusahaan, serta mendorong jalannya perilaku OCB. Dengan adanya persepsi OCB yang berfokus pada peran perilaku karyawan di tempat kerja telah menunjukkan bahwa OCB telah mempengaruhi sikap para pekerja. Selain itu, keberhasilan perusahaan dalam menerapkan komitmen organisasi dibuktikan dengan adanya budaya organisasi diantara karyawan yang akan mempengaruhi setiap tindakan maupun perilaku yang ditunjukkan.

Penelitian Khan dan Rashid (2012); Ariani et al., (2017) menunjukkan hasil bahwa komitmen organisasional merupakan variabel mediasi yang baik untuk mengetahui hubungan antara budaya organisasi, gaya kepemimpinan, dan keadilan organisasi terhadap OCB. Penelitian lainnya dari Ardi dan Sudarma (2015) menunjukkan bahwa komitmen organisasi terbukti memediasi pengaruh persepsi dukungan dan keadilan organisasi terhadap OCB. Berdasarkan uraian di atas, maka dapat dirumuskan hipotesis sebagai berikut:

$\mathrm{H}_{4}$ : Terdapat Pengaruh Positif Budaya Organisasi terhadap Organizational Citizenship Behavior (OCB) dengan Komitmen Organisasi sebagai Variabel Mediasi. 


\subsection{Model Penelitian}

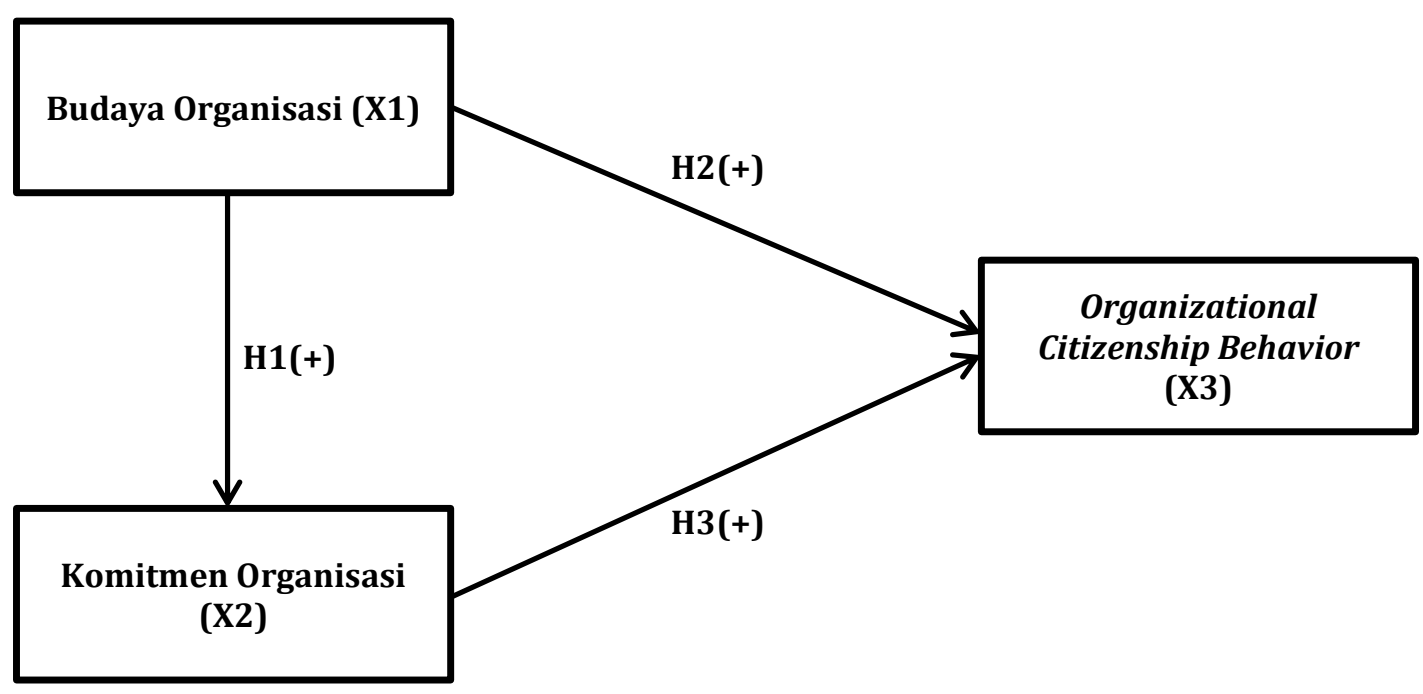

Gambar 1. Model Penelitian

\section{Metode Penelitian}

\subsection{Populasi dan Sampel}

Populasi adalah suatu kelompok atau kumpulan objek yang akan digeneralisasikan dari hasil penelitian (Widiyanto, 2010). Populasi dalam penelitian ini yaitu pegawai Badan Keuangan dan Aset Daerah (BKAD) Kabupaten Sleman, dimana populasi ini mencakup seluruh pegawai yang berjumlah 100 orang.

Teknik pengambilan sampel untuk menentukan sampel yang akan digunakan dalam penelitian ini menggunakan model non probability sampling dengan menggunakan teknik sampel jenuh. Sugiyono (2014) menjelaskan sampel jenuh merupakan teknik penentuan sampel dimana semua anggota populasi akan dijadikan sebagai sampel penelitian. Dalam penelitian ini semua anggota populasi menjadi sampel penelitian yang berjumlah 100 pegawai.

\subsection{Teknik Analisis Data}

\subsubsection{Uji Validitas}

Menurut Ghozali (2011) uji validitas dapat digunakan untuk mengukur sah atau tidaknya kuesioner. Untuk melakukan uji validitas dapat menggunakan program SPSS. Suatu pengukuran dikatakan valid jika pertanyaan pada kuesioner mampu untuk mengungkapkan sesuatu yang akan diukur oleh kuesioner tersebut. Untuk mengukur validitas dapat dilakukan dengan cara membandingkan antara skor butir pertanyaan dengan total skor konstruk atau variabel. Sedangkan untuk mengetahui skor masingmasing item pertanyaan valid atau tidak, maka ditetapkan kriteria statistik sebagai berikut:

a) Jika r-hitung > r-tabel, maka variabel tersebut dinyatakan valid.

b) Jika r-hitung $<$ r-tabel, maka variabel tersebut dinyatakan tidak valid.

\subsubsection{Uji Reliabilitas}

Menurut Ghozali (2011) reliabilitas adalah alat untuk mengukur suatu kuisioner yang merupakan indikator dari variabel atau konstruk. Suatu kuisioner dikatakan reliabel jika jawaban seseorang terhadap pertanyaan adalah konstan atau stabil. Pengukuran reliabilitas ini dilakukan dengan cara one shot atau pengukuran sekali dan kemudian dibandingkan dengan pertanyaan lain atau mengukur korelasi antar jawaban 
pertanyaan dan pengukuran dengan cara repeated measure atau pengukuran berulang. Seseorang akan disodori pertanyaan yang sama pada waktu yang berbeda dan kemudian dapat dilihat apakah dia tetap konsisten dengan jawabannya atau tidak. Pengukuran reliabilitas dengan uji statistik cronbach's alpha $(\alpha)$, serta konstruk atau variabel dikatakan reliabel, jika memberikan nilai cronbach's alpha $(\alpha)>0,60$ (Ghozali, 2011).

\subsection{Analisis Deskriptif}

Analisis deskriptif digunakan untuk menganalisis dan menyajikan data kuantitatif dengan tujuan untuk mengetahui gambaran perusahaan yang dijadikan sampel penelitian. Dengan menggunakan analisis deskriptif, maka dapat diketahui nilai rata-rata (mean), standar deviasi, maksimum dan minimum (Ghozali, 2011).

Analisis ini juga menggambarkan jawaban responden dari kuesioner yang diajukan atau disebarkan. Karakteristik responden yang digunakan dalam penelitian ini berdasarkan jenis kelamin, usia, serta pendidikan dari responden. Analisis ini juga dapat menggambarkan jawaban responden dari kuesioner yang disebarkan. Pada bagian ini peneliti akan menganalisis data berdasarkan pada jawaban kuesioner yang telah diisi.

\subsection{Uji Asumsi Klasik}

\subsubsection{Uji Normalitas}

Uji normalitas ini digunakan untuk menguji apakah di dalam model regresi, data variabel dependen dan independen yang digunakan memiliki distribusi normal atau tidak. Ghozali (2011) menjelaskan uji normalitas bertujuan untuk menguji apakah dalam model regresi variabel pengganggu residual berkontribusi normal. Diketahui bahwa uji T dan uji F mengasumsikan bahwa nilai residual mengikuti distribusi normal. Apabila asumsi ini dilanggar, maka uji statistik menjadi tidak valid untuk jumlah sampel kecil. Pengujian uji normalitas dalam penelitian ini menggunakan uji statistik normal probability plot dan kolmogorov-smirnov test. Pengujian ini dilakukan dengan menilai 2tailed melalui pengaruh tingkat signifikansi 5\%. Data dikatakan normal apabila Asymp. Sig (2-tailed) lebih besar dari 0,05. Jika nilai signifikansi < 0,05, maka dapat disimpulkan bahwa data penelitian memiliki distribusi residual normal.

\subsubsection{Uji Heteroskedastisitas}

Menurut Ghozali (2011) uji heterokedastisitas bertujuan untuk menguji sama atau tidak varian dan residual dari observasi satu dengan observasi yang lainnya. Jika residualnya mempunyai varian yang sama disebut homokedastisitas, tetapi jika variannya tidak sama disebut heteroskedastisitas. Cara mendeteksi ada tidaknya heteroskedastisitas dengan cara melihat grafik plot antara nilai prediksi variabel terikat atau dependen, yaitu ZPRED dengan residualnya SREID, dapat dilihat dengan ada tidaknya pola penentu pada grafik scatter plot antara SREID dan ZPRED dimana sumbu $\mathrm{Y}$ adalah $\mathrm{Y}$ yang diprediksi, dan sumbu $\mathrm{X}$ adalah residual ( $\mathrm{Y}$ prediksi - Y sesungguhnya) yang telah distudentized. Selain itu untuk menguji heteroskedastisitas dapat menggunakan uji glejser, yaitu jika nilai signifikansi lebih besar dari 0,05, maka kesimpulannya adalah tidak terjadi gejala heteroskedastisitas dalam model regresi.

\subsubsection{Uji Multikolinearitas}

Multikolinearitas adalah situasi dimana terdapat korelasi antara variabel bebas diantara satu dengan lainnya. Uji multikolinearitas bertujuan untuk menguji apakah model regresi ditemukan adanya korelasi antara variabel bebas (independen). Kriteria pengujian pada uji multikolinearitas, nilai tolerance $>0,10$ atau sama dengan nilai VIF $<$ 10 yang menunjukkan adanya multikolinearitas antara variabel independen dalam 
model regresi (Ghozali, 2011).

\subsection{Analisis Regresi Linier Berganda}

Pengujian analisis menggunakan analisis regresi berganda yang dioperasikan melalui program SPSS. Menurut Sugiyono (2014) analisis regresi berganda digunakan untuk mengetahui pengaruh dari variabel bebas (X) terhadap variabel terikat (Y). Persamaan ini menggunakan persamaan regresi sebagai berikut:

\subsubsection{Regresi Model 1}

Analisis regresi model 1 digunakan untuk mengetahui pengaruh budaya organisasi terhadap komitmen organisasi. Persamaan regresi sebagai berikut:

Keterangan:

$$
Z=\alpha+\beta_{1} X
$$

$\mathrm{Z}=$ Komitmen Organisasi

$\mathrm{X}=$ Budaya Organisasi

$\alpha=$ Konstanta

$\beta_{1}=$ Koefisien Regresi Budaya Organisasi

\subsubsection{Regresi Model 2}

Analisis regresi model 2 digunakan untuk mengetahui pengaruh budaya organisasi dan komitmen organisasi terhadap Organizational Citizenship Behavior (OCB). Persamaan regresi sebagai berikut:

Keterangan:

$$
Y=\alpha+\beta_{1} X+\beta_{2} Z
$$

$\mathrm{Y} \quad=$ Organizational Citizenship Behavior (OCB)

$\mathrm{X} \quad$ = Budaya Organisasi

$\mathrm{Z} \quad=$ Komitmen Organisasi

$\alpha \quad=$ Konstanta

$\beta_{1} \quad=$ Koefisien Regresi Budaya Organisasi

$\beta_{2}=$ Koefisien Regresi Komitmen Organisasi

\subsection{Uji Hipotesis}

\subsubsection{Uji Parsial (Uji T)}

Uji T dilakukan untuk mengetahui seberapa jauh pengaruh variabel independen secara individu dalam menerangkan variasi variabel dependen (Ghozali, 2011). Kriteria dalam menentukan uji $\mathrm{T}$ adalah ketika signifikansi $<0,05$ atau $=0,05$, maka dapat dikatakan bahwa suatu variabel independen mempengaruhi variabel dependen atau hipotesis diterima. Jika nilai signifikansi lebih besar, maka dapat dikatakan hipotesis ditolak (Ghozali, 2011). Ho diterima apabila t-hitung < t-tabel, maka Ho diterima. Ho ditolak apabila t-hitung > t-tabel, maka Ho ditolak.

\subsubsection{Uji Koefisien Determinan}

Koefisien determinan digunakan untuk mengukur seberapa jauh kemampuan model dalam menerangkan variasi variabel dependen. Koefisien determinan $\left(\mathrm{R}^{2}\right)$ dimaksudkan untuk mengetahui tingkat ketepatan paling baik di dalam analisis regresi. Nilai yang mendekati 1, berarti model regresi variabel independen terhadap dependen sangat berpengaruh sebesar nilai $\mathrm{R}^{2}$ dan sebaliknya (Ghozali, 2011).

\subsubsection{Uji Sobel}

Dalam penelitian ini uji sobel digunakan guna mengetahui pengaruh variabel mediasi yaitu komitmen organisasi. Pengujian hipotesis ini dapat dilakukan dengan sobel test menurut Gilal et al., (2017) dengan rumus sebagai berikut: 


$$
Z=\frac{a b}{\sqrt{b^{2} S E a^{2}+\left(a^{2} S E b^{2}\right)}}
$$

Dimana:

$\mathrm{a} \quad=$ koefisien regresi variabel independen terhadap variabel mediasi

$\mathrm{b} \quad=$ koefisien regresi variabel mediasi terhadap variabel dependen

SEa = standard error of estimation dari pengaruh variabel independen terhadap variabel mediasi

$\mathrm{SEb}=$ standard error of estimation dari pengaruh variabel mediasi terhadap variabel dependen

Untuk menguji signifikan atau tidak, maka digunakan nilai probabilitas kesalahan, dimana nilai kesalahan 5\% tersebut jika menggunakan normal batas adalah 1,998. Jika nilai $\mathrm{Z}$ hitung $<1,98$, maka tidak signifikan, begitu juga sebaliknya jika $\mathrm{Z}$ hitung $>1,98$, maka signifikan.

\section{Hasil dan Pembahasan}

\subsection{Data Penelitian}

Data penelitian ini adalah responden pegawai Badan Keuangan dan Aset Daerah (BKAD) Kabupaten Sleman dengan menggunakan instrumen kuesioner. Berdasarkan penentuan teknik pengambilan sampel dengan metode sampel jenuh, maka kuesioner yang terjawab lengkap dan layak untuk dianalisis dalam penelitian ini adalah 100 kuesioner yang sesuai dengan jumlah sampel yang ada yaitu 100 responden.

\subsection{Teknik Analisis Data}

\subsubsection{Uji Validitas}

Tabel 1. Hasil Uji Validitas Variabel Budaya Organisasi

\begin{tabular}{cccc}
\hline Indikator & R-Hitung & R-Tabel & Keterangan \\
\hline B01 & 0,559 & 0,1654 & Valid \\
B02 & 0,614 & 0,1654 & Valid \\
B03 & 0,496 & 0,1654 & Valid \\
B04 & 0,298 & 0,1654 & Valid \\
B05 & 0,257 & 0,1654 & Valid \\
B06 & 0,380 & 0,1654 & Valid \\
B07 & 0,287 & 0,1654 & Valid \\
\hline
\end{tabular}

Tabel 1 menunjukkan hasil uji validitas variabel budaya organisasi yang dilakukan dengan membandingkan $r$-hitung dengan $r$-tabel untuk (df) $=n-2$ pada tingkat signifikansi. Suatu indikator dinyatakan valid apabila r-hitung $>$ r-tabel. Jumlah data dalam penelitian ini $(\mathrm{df})=100-2=98$ dengan hasil korelasi koefisien seluruhnya mempunyai nilai r-hitung > r-tabel sebesar 0,1654. Dengan demikian dapat dinyatakan bahwa seluruh butir dari variabel budaya organisasi dinyatakan valid. 
Tabel 2. Hasil Uji Validitas Variabel Organizational Citizenship Behavior (OCB)

\begin{tabular}{cccc}
\hline Indikator & R-Hitung & R-Tabel & Keterangan \\
\hline OCB1 & 0,470 & 0,1654 & Valid \\
OCB2 & 0,607 & 0,1654 & Valid \\
OCB3 & 0,344 & 0,1654 & Valid \\
OCB4 & 0,524 & 0,1654 & Valid \\
OCB5 & 0,465 & 0,1654 & Valid \\
OCB6 & 0,474 & 0,1654 & Valid \\
OCB7 & 0,408 & 0,1654 & Valid \\
\hline
\end{tabular}

Tabel 2 menjelaskan hasil uji validitas variabel OCB yang dilakukan dengan membandingkan $r$-hitung > r-tabel sebesar 0,1654. Dengan demikian dapat dinyatakan bahwa seluruh butir dari variabel OCB dinyatakan valid.

Tabel 3. Hasil Uji Validitas Variabel Komitmen Organisasi

\begin{tabular}{cccc}
\hline Indikator & R-Hitung & R-Tabel & Keterangan \\
\hline K01 & 0,587 & 0,1654 & Valid \\
K02 & 0,369 & 0,1654 & Valid \\
K03 & 0,531 & 0,1654 & Valid \\
K04 & 0,229 & 0,1654 & Valid \\
K05 & 0,440 & 0,1654 & Valid \\
K06 & 0,200 & 0,1654 & Valid \\
K07 & 0,336 & 0,1654 & Valid \\
\hline
\end{tabular}

Tabel 3 menunjukkan hasil uji validitas variabel komitmen organisasi yang dilakukan dengan membandingkan r-hitung > r-tabel sebesar 0,1654. Dengan demikian dapat dinyatakan bahwa seluruh butir dari variabel komitmen organisasi dinyatakan valid.

\subsubsection{Uji Reliabilitas}

Tabel 4. Hasil Uji Reliabilitas

\begin{tabular}{cccc}
\hline Variabel & $\begin{array}{c}\text { Cronbach's } \\
\text { Alpha }\end{array}$ & Nilai Kritis & Keterangan \\
\hline $\begin{array}{c}\text { Budaya Organisasi } \\
\text { (BO) }\end{array}$ & 0,703 & 0,6 & Reliabel \\
$\begin{array}{c}\text { Organizational } \\
\text { Citizenship } \\
\text { Behavior (OCB) } \\
\text { Komitmen }\end{array}$ & 0,752 & 0,6 & Reliabel \\
Organisasi (KO) & 0,670 & 0,6 & Reliabel \\
\hline
\end{tabular}

Tabel 4 menjelaskan hasil uji reliabilitas yang mana masing-masing variabel memberikan nilai cronbach's alpha $>0,6$, sehingga dapat disimpulkan bahwa seluruh variabel dalam penelitian ini dinyatakan reliabel. 
4.3. Karakteristik Responden

\subsubsection{Berdasarkan Jenis Kelamin}

Tabel 5. Karakteristik Responden Berdasarkan Jenis Kelamin

\begin{tabular}{ccc}
\hline Jenis Kelamin & Jumlah & Persentase \\
\hline Laki-Laki & 55 & $55 \%$ \\
Perempuan & 45 & $45 \%$ \\
Jumlah & 100 & $100 \%$ \\
\hline
\end{tabular}

Tabel 5 menunjukkan data bahwa responden yang berpartisipasi dalam penelitian ini berjumlah 100 orang. Responden yang berjenis kelamin laki-laki berjumlah 55 orang dengan persentase 55\%, sedangkan responden dengan jenis kelamin perempuan berjumlah 45 orang dengan persentase $45 \%$.

\subsubsection{Berdasarkan Usia}

Tabel 6. Karakteristik Responden Berdasarkan Usia

\begin{tabular}{ccc}
\hline Usia & Jumlah & Persentase \\
\hline 20-35 Tahun & 25 & $25 \%$ \\
35-45 Tahun & 40 & $40 \%$ \\
>45 Tahun & 35 & $35 \%$ \\
Jumlah & 100 & $100 \%$ \\
\hline
\end{tabular}

Tabel 6 menunjukkan data rentang usia responden mulai dari 20 tahun sampai dengan lebih dari 45 tahun. Usia 20-35 tahun berjumlah 25 orang dengan persentase $25 \%$. Usia $35-45 \%$ berjumlah 40 orang dengan persentase $40 \%$. Sedangkan usia di atas 45 tahun berjumlah 35 orang dengan persentase $35 \%$.

\subsubsection{Berdasarkan Pendidikan Terakhir}

Tabel 7. Karakteristik Responden Berdasarkan Usia

\begin{tabular}{ccc}
\hline Pendidikan & Jumlah & Persentase \\
\hline SMA & 19 & $19 \%$ \\
Diploma & 22 & $22 \%$ \\
Sarjana & 59 & $59 \%$ \\
Jumlah & 100 & $100 \%$ \\
\hline
\end{tabular}

Tabel 7 menjelaskan bahwa responden dalam kategori pendidikan dengan jenjang SMA berjumlah 19 orang dengan persentase 19\%, responden tingkat pendidikan diploma berjumlah 22 orang dengan persentase $22 \%$, sedangkan tingkat pendidikan sarjana berjumlah 59 orang dengan persentase $59 \%$.

\subsection{Uji Asumsi Klasik}

\subsubsection{Uji Normalitas}

Uji normalitas ini digunakan untuk menguji apakah di dalam model regresi data variabel dependen dan independen yang digunakan memiliki distribusi normal atau tidak. Uji normalitas dalam penelitian ini dilakukan dengan cara melihat grafik non probability plot. Gambar 2 grafik non probability plot model I yang menunjukkan bahwa data menyebar di sekitar garis diagonal dan mengikuti arah garis diagonal. Gambar 3 grafik non probability plot model I menunjukkan data menyebar di sekitar garis diagonal, maka dapat dinyatakan bahwa data tersebut normal. 


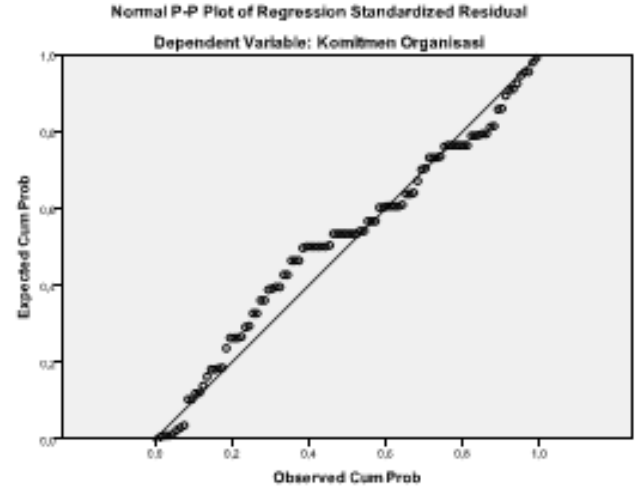

Gambar 2. Grafik Non Probability Plot Model I

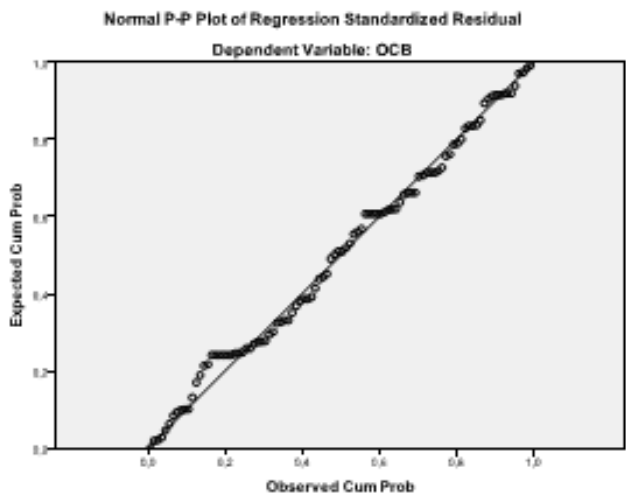

Gambar 3. Grafik Non Probability Plot Model II

Selain menguji dengan grafik non probability plot, normalitas dapat diuji dengan menggunakan uji Kolmogrov-Smirov (K-S), dengan melihat nilai signifikansinya. Data dinyatakan normal jika nilai signifikansi $>0,05$.

Tabel 8. Hasil Uji Kolmogorov-Smirnov Model I

\begin{tabular}{cc}
\hline & Jumlah \\
\hline Kolmogorov-Smirnov $Z$ & 1,182 \\
Asymp. Sig. (2-tailed) & 0,122 \\
\hline
\end{tabular}

Tabel 8 menjelaskan bahwa hasil uji normalitas mengunakan uji KolmogrovSmirnov dengan hasil pengolahan data pada Asymp. Sig. (2-tailed) menunjukkan tingkat singnifikansi 0,122. Tingkat signifikansi $>0,05$ berarti data tersebut dinyatakan normal.

Tabel 9. Hasil Uji Kolmogorov-Smirnov Model II

\begin{tabular}{cc}
\hline & Jumlah \\
\hline Kolmogorov-Smirnov $Z$ & 0,799 \\
Asymp. Sig. (2-tailed) & 0,546 \\
\hline
\end{tabular}

Selanjutnya tabel 9 dengan nilai signifikansi sebesar 0,546 yang berarti lebih besar dari 0,05, maka data tersebut dinyatakan normal. 


\subsubsection{Uji Multikolinearitas}

Tabel 10. Hasil Uji Multikolinearitas

\begin{tabular}{cccc}
\hline Variabel & Tolerance & VIF & Keterangan \\
\hline Budaya Organisasi & 0,938 & 1,066 & $\begin{array}{c}\text { Tidak terjadi } \\
\text { multikolinearitas } \\
\text { Tidak terjadi } \\
\text { Komitmen }\end{array}$ \\
$\begin{array}{c}\text { Organisasi } \\
\text { multikolinearitas }\end{array}$ \\
\hline
\end{tabular}

Tabel 10 menunjukkan hasil uji multikolinearitas variabel budaya organisasi terhadap OCB dengan nilai VIF sebesar 1,066 < 10, dan nilai tolerance sebesar 0,938 > 0,1 . Variabel komitmen organisasi terhadap OCB yang menunjukkan nilai VIF sebesar $1,066<10$ dan nilai tolerance sebesar $0,938>0,1$. Kedua variabel tersebut terbebas dari masalah multikolinearitas karena nilai $\mathrm{VIF}<10$ dan nilai tolerance $>0,1$.

\subsubsection{Uji Heteroskedastisitas}

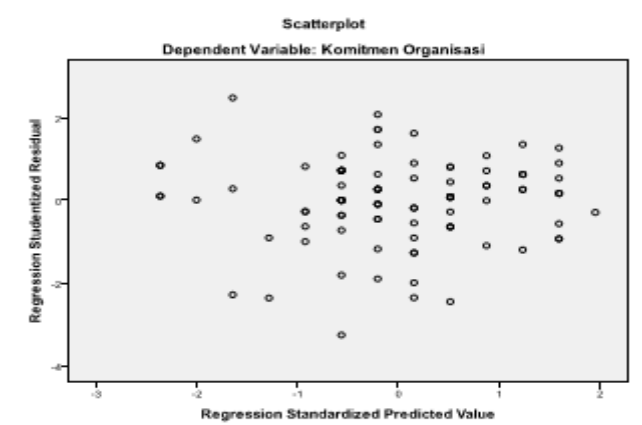

Gambar 4. Grafik Scatter Plot Model I

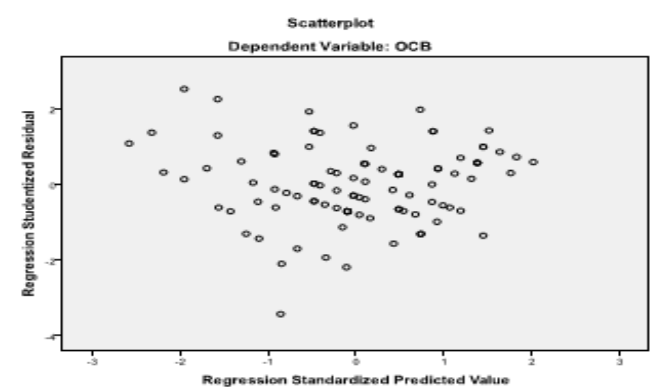

Gambar 5. Grafik Scatter Plot Model II

Gambar 4 dan 5 menunjukkan bahwa tidak ada pola yang jelas, serta titik menyebar di atas dan di bawah angka 0 pada sumbu Y, sehingga dapat diambil kesimpulan bahwa dalam model regresi ini tidak terjadi heteroskedastisitas. Selain menggunakan grafik scatter plot, uji heteroskedastisitas dapat dilakukan pengujian dengan menggunakan uji glejser yaitu dengan melihat nilai absolute variabel independennya.

Tabel 11. Hasil Uji Glejser Model I

\begin{tabular}{cccccc}
\hline Model & \multicolumn{2}{c}{$\begin{array}{c}\text { Unstandardized } \\
\text { Coefficients } \\
\text { Std. Error }\end{array}$} & $\begin{array}{c}\text { Standardized } \\
\text { Coefficients } \\
\text { Beta }\end{array}$ & t & Sig. \\
\hline B & 4,340 & 2,017 & & 2,152 & 0,034 \\
Budaya & $-0,078$ & 0,068 & $-0,116$ & $-1,153$ & 0,252 \\
Organisasi & & & & & \\
\hline
\end{tabular}


Tabel 12. Hasil Uji Glejser Model II

\begin{tabular}{|c|c|c|c|c|c|}
\hline \multirow[t]{2}{*}{ Model } & \multicolumn{2}{|c|}{$\begin{array}{l}\text { Unstandardized } \\
\text { Coefficients }\end{array}$} & \multirow{2}{*}{$\begin{array}{l}\text { Standardized } \\
\text { Coefficients } \\
\text { Beta }\end{array}$} & \multirow[t]{2}{*}{$T$} & \multirow[t]{2}{*}{ Sig. } \\
\hline & B & Std. Error & & & \\
\hline Constant & 4,523 & 1,756 & & 2,576 & 0,011 \\
\hline Budaya & $-0,055$ & 0,049 & $-0,115$ & $-1,113$ & 0,268 \\
\hline $\begin{array}{l}\text { Organisasi } \\
\text { Komitmen } \\
\text { Organisasi }\end{array}$ & $-0,041$ & 0,048 & $-0,089$ & $-0,865$ & 0,389 \\
\hline
\end{tabular}

Tabel 11 menunjukkan hasil uji heteroskedastisitas model I melalui uji glejser dengan nilai signifikansi 0,252 yang lebih besar dari 0,05. Selanjutnya tabel 12 menunjukkan hasil uji Model II melalui uji glejser dengan nilai signifikansi 0,268 dan 0,389 yang mana lebih besar dari 0,05. Maka dapat disimpulkan bahwa data penelitian ini tidak terjadi masalah heteroskedastisitas.

4.5. Analisis Regresi Linear Berganda

Tabel 13. Hasil Analisis Regresi Linear Berganda Model I

\begin{tabular}{cccccc}
\hline Model & \multicolumn{2}{c}{$\begin{array}{c}\text { Unstandardized } \\
\text { Coefficients } \\
\text { Std. Error }\end{array}$} & $\begin{array}{c}\text { Standardized } \\
\text { Coefficients } \\
\text { Beta }\end{array}$ & T & Sig. \\
\hline B & 21,818 & 2,991 & & 7,296 & 0,000 \\
Budaya & 0,256 & 0,101 & 0,249 & 2,543 & 0,013 \\
Organisasi & & & & & \\
\hline
\end{tabular}

Tabel 13 menunjukkan persamaan regresi linear berganda model I sebagai berikut:

$$
Z=\mathbf{2 1 , 8 1 8}+\mathbf{0 , 2 5 6 X}
$$

1) Konstanta

Dari hasil persamaan uji regresi linear berganda, diperoleh nilai konstanta sebesar 21,818. Artinya walaupun tidak ada variabel budaya organisasi (X) yang mempengaruhi komitmen organisasi, maka nilai komitmen organisasi tersebut sebesar $21,818$.

2) Koefisien Regresi $\left(\beta_{1}\right)$

Nilai koefisien regresi $\left(\beta_{1}\right)$ sebesar 0,256 . Artinya, jika variabel budaya organisasi meningkat sebesar satu satuan, maka komitmen organisasi akan meningkat sebesar 0,256 .

Tabel 14. Hasil Analisis Regresi Linear Berganda Model I

\begin{tabular}{cccccc}
\hline Model & \multicolumn{2}{c}{$\begin{array}{c}\text { Unstandardized } \\
\text { Coefficients } \\
\text { Std. Error }\end{array}$} & $\begin{array}{c}\text { Standardized } \\
\text { Coefficients } \\
\text { Beta }\end{array}$ & T & Sig. \\
\hline B & 2,902 & & 3,306 & 0,001 \\
Budaya & 0,596 & 0,081 & 0,412 & 4,818 & 0,000 \\
$\begin{array}{c}\text { Organisasi } \\
\text { Komitmen }\end{array}$ & 0,289 & 0,079 & 0,314 & 3,666 & 0,000 \\
Organisasi & & & & & \\
\hline
\end{tabular}
berikut:

Tabel 14 di atas menunjukkan persamaan regresi linear berganda model II sebagai

$$
\mathbf{Y}=\mathbf{a}+\beta_{1} \mathbf{X}+\beta_{2} \mathbf{Z}
$$


1) Konstanta

Dari hasil persamaan uji regresi linear berganda, diperoleh nilai konstanta sebesar 9,596. Artinya walaupun tidak ada variabel budaya organisasi (X) dan komitmen organisasi (Z) yang mempengaruhi OCB, maka nilai OCB tersebut sebesar 9,596.

2) Koefisien Regresi $\left(\beta_{1}\right)$

Nilai koefisien regresi $\left(\beta_{1}\right)$ sebesar 0,391 . Artinya, jika variabel budaya organisasi meningkat sebesar satu satuan, maka OCB akan meningkat sebesar 0,391.

3) Koefisien Regresi (Z)

Nilai koefisien regresi (Z) sebesar 0,289. Artinya, jika variabel komitmen organisasi meningkat sebesar satu satuan, maka OCB akan meningkat sebesar 0,289.

\subsection{Uji Hipotesis}

\subsubsection{Uji Parsial (Uji T)}

\begin{tabular}{cccccc}
\hline Model & \multicolumn{2}{c}{$\begin{array}{c}\text { Unstandardized } \\
\text { Coefficients }\end{array}$} & $\begin{array}{c}\text { Standardized } \\
\text { Coefficients }\end{array}$ & T & Sig. \\
& B & Std. Error & Beta & & \\
\hline Constant & 21,818 & 2,991 & & 7,296 & 0,000 \\
Budaya & 0,256 & 0,101 & 0,249 & 2,543 & 0,013 \\
Organisasi & & & & & \\
\hline
\end{tabular}

Tabel 15 menjelaskan bahwa variabel budaya organisasi memiliki nilai t-hitung sebesar 2,543 yang lebih besar dari t-tabel sebesar 1,660 dengan tingkat signifikansi $0,013 / 2=0,0065<0,05$. Artinya, hipotesis pertama yang mengatakan budaya organisasi berpengaruh positif terhadap komitmen organisasi diterima.

Tabel 16. Hasil Uji Parsial (Uji T) Model II

\begin{tabular}{|c|c|c|c|c|c|}
\hline \multirow[t]{2}{*}{ Model } & \multicolumn{2}{|c|}{$\begin{array}{l}\text { Unstandardized } \\
\text { Coefficients }\end{array}$} & \multirow{2}{*}{$\begin{array}{c}\text { Standardized } \\
\text { Coefficients } \\
\text { Beta }\end{array}$} & \multirow[t]{2}{*}{$T$} & \multirow[t]{2}{*}{ Sig. } \\
\hline & B & Std. Error & & & \\
\hline Constant & 9,596 & 2,902 & & 3,306 & 0,001 \\
\hline Budaya & 0,391 & 0,081 & 0,412 & 4,818 & 0,000 \\
\hline Organisasi & & & & & \\
\hline $\begin{array}{l}\text { Komitmen } \\
\text { Organisasi }\end{array}$ & 0,289 & 0,079 & 0,314 & 3,666 & 0,000 \\
\hline
\end{tabular}

Tabel 16 menjelaskan bahwa budaya organisasi memiliki nilai t-hitung sebesar $4,818>1,660$ dengan nilai signifikansi $0,000 / 2=0<0,05$, maka dapat disimpulkan hipotesis kedua yang mengatakan budaya organisasi berpengaruh positif terhadap OCB diterima. Selanjutnya komitmen organisasi memiliki nilai t-hitung sebesar 3,666 > 1,660 dengan nilai signifikansi $0,002 / 2=0,001<0,05$, maka dapat disimpulkan bahwa hipotesis ketiga yang mengatakan komitmen organisasi berpengaruh positif terhadap OCB diterima.

\subsubsection{Uji Koefisien Determinasi}

Tabel 17. Hasil Uji Koefisien Determinasi

\begin{tabular}{ccccc}
\hline Model & R & R-Square & $\begin{array}{c}\text { Adjusted R- } \\
\text { Square }\end{array}$ & $\begin{array}{c}\text { Std. Error of the } \\
\text { Estimate }\end{array}$ \\
\hline 1 & 0,577 & 0,333 & 0,319 & 2,175 \\
\hline
\end{tabular}


Tabel 17 menjelaskan bahwa kedua variabel independen mempengaruhi variabel dependen sebesar 0,319 atau sebesar 31,9\%. Hal ini menunjukkan bahwa sisanya sebesar $68,1 \%$ variabel dependen dipengaruhi oleh variabel lain yang tidak diteliti dalam penelitian ini.

\subsubsection{Uji Sobel}

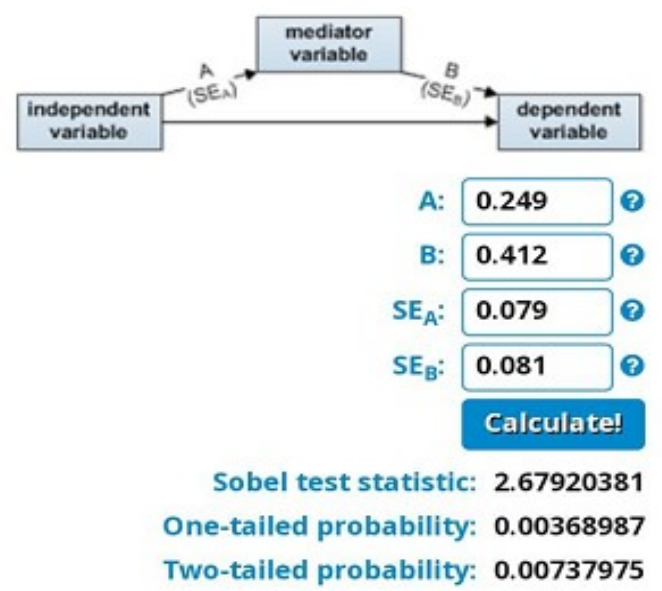

Gambar 6. Hasil Sobel Test Statistic

Berdasarkan hasil perhitungan uji sobel pada gambar 6 diperoleh nilai z sebesar 2,64518627 yang mana lebih besar dari 1,98 dengan tingkat signifikansi $5 \%$. Artinya, komitmen organisasi mampu memediasi budaya organisasi terhadap OCB.

\subsection{Pembahasan}

\subsubsection{Pengaruh Positif Budaya Organisasi terhadap Komitmen Organisasi}

Berdasarkan hasil analisis data diketahui variabel budaya organisasi berpengaruh positif terhadap komitmen organisasi di Badan Keuangan dan Aset Daerah Kabupaten Sleman. Dengan nilai signifikansi 0,013/2 =0,0065 $<0,05$, maka dapat disimpulkan hipotesis pertama yang mengatakan budaya organisasi berpengaruh positif terhadap komitmen organisasi diterima. Budaya organisasi sangat baik untuk diterapkan di dalam organisasi, karena budaya organisasi memiliki tujuan untuk mengubah sikap dan juga perilaku sumber daya manusia yang ada agar dapat meningkatkan produktivitas kerja untuk menghadapi berbagai tantangan dimasa yang akan datang.

Adapun manfaat dari penerapan budaya organisasi adalah dapat meningkatkan kebersamaan, gotong royong, membangun komunikasi yang baik, meningkatkan produktivitas kerja, dan sebagai seorang pemimpin perusahaan tetap menjaga adanya budaya organisasi di dalam perusahaan agar pegawai tanggap dalam perkembangan yang semakin maju. Hasil akhir dari penerapan budaya organisasi yang baik dalam perusahaan dapat memicu peningkatan komitmen dari karyawan terhadap perusahaan. Hasil penelitian ini sesuai dengan penelitian terdahulu yang dilakukan oleh Sari (2013), Sumanto dan Hermaningsih (2016), Fasisca dan Fahmy (2018) yang menunjukkan bahwa budaya organisasi berpengaruh positif terhadap komitmen organisasi.

\subsubsection{Pengaruh Positif Budaya Organisasi terhadap Organizational Citizenship Behavior (OCB)}

Berdasarkan hasil analisis data diketahui variabel budaya organisasi berpengaruh positif terhadap OCB di Badan Keuangan dan Aset Daerah Kabupaten Sleman. Dengan nilai signifikansi 0,000/2 $=0<0,05$, maka dapat disimpulkan hipotesis kedua yang mengatakan budaya organisasi berpengaruh positif terhadap OCB diterima.

Andira Ramadha Arundita et al., (Pengaruh Budaya Organisasi terhadap Organizational 
Penerapan budaya organisasi terhadap OCB yang tercermin dalam membantu rekan kerja, membantu pelayanan terhadap siapapun, keterlibatan dalam fungsi dan kegiatan perusahaan atau instansi. Pegawai yang sudah memahami nilai yang ada dalam budaya organisasi berpengaruh terhadap perilaku OCB.

Hal ini sangat menentukan bagi seluruh pegawai dalam menjalankan tugasnya, berinteraksi dengan lingkungannya secara internal dan hubungan antara bawahan dan atasan. Hasil penelitian ini sesuai dengan penelitian terdahulu yang dilakukan oleh Sari dan Hajriani (2015), Rosyada dan Rahadjo (2016), Fasisca dan Fahmy (2018) yang menunjukkan bahwa budaya organisasi berpengaruh positif terhadap OCB

\subsubsection{Pengaruh Positif Komitmen Organisasi terhadap Organizational Citizenship Behavior (OCB)}

Berdasarkan hasil analisis data diketahui variabel komitmen organisasi berpengaruh positif terhadap OCB di Badan Aset Daerah Kabupaten Sleman. Dengan nilai signifikansi $0,002 / 2=0,001<0,05$, maka dapat disimpulkan bahwa hipotesis ketiga yang mengatakan komitmen organisasi berpengaruh positif terhadap OCB diterima. Komitmen organisasi dalam pelaksanaannya tercermin dari ikatan emosional terhadap organisasi, loyalitas dan merekomendasikan hal-hal positif tentang organisasi, serta memegang teguh visi dan misi. Dengan tingkat pendidikan pegawai yang tinggi dan kemampuan kerja pegawai yang memadai, maka komitmen organisasi akan lebih baik, sehingga perilaku OCB akan berjalan dengan baik. Komitmen organisasi berhubungan dengan lingkungan kerja, dan komitmen organisasi dibuat untuk memberikan kemudahan pencapaian tujuan organisasi dan pemberian reward untuk pegawai yang berhasil menjalankan komitmen dengan baik. Hasil penelitian ini sesuai dengan penelitian terdahulu yang dilakukan oleh Kurniawan (2015), Lubis (2015), Rosyada dan Rahadjo (2016) yang menunjukkan bahwa komitmen organisasi berpengaruh positif terhadap OCB pada karyawan.

\subsubsection{Peran Mediasi Komitmen Organisasi pada Pengaruh Positif Budaya Organisasi terhadap Organizational Citizenship Behavior (OCB)}

Dari hasil perhitungan uji sobel didapatkan nilai Z sebesar 2,64518627, karena nilai $\mathrm{Z}=2,64518627>1,98$ dengan tingkat signifikansi 5\%, maka dapat dikatakan bahwa komitmen organisasi mampu memediasi pengaruh positif budaya organisasi terhadap OCB. Penerapan budaya organisasi yang baik dalam suatu perusahaan memicu peningkatan komitmen karyawan terhadap perusahaan dan diikuti dengan peningkatan OCB. Hal tersebut dikarenakan budaya organisasi yang baik mampu membangun kerjasama antar karyawan, menciptakan komunikasi yang baik dan juga memacu produktivitas karyawan yang kemudian diikuti dengan rasa kepedulian antar karyawan dalam perusahaan. Hasil penelitian ini sesuai dengan penelitian sebelumnya yang dilakukan Ariani et al., (2017) dengan hasil budaya organisasi berpengaruh langsung terhadap komitmen afektif dan OCB, begitupula komitmen afektif berpengaruh langsung terhadap OCB. Komitmen afektif memediasi secara parsial pengaruh antara budaya organisasi dan OCB. Penelitian yang dilakukan oleh Khan dan Rashid (2012) serta Ardi dan Sudarma (2015) menunjukkan bahwa diantara semua variabel, komitmen organisasi menjadi variabel yang paling berpengaruh signifikan dalam menjelaskan pemeran OCB diantara karyawan yang memberikan hasil optimis dalam memilih komitmen organisasi sebagai variabel mediasi untuk budaya organisasi, gaya kepemimpinan, dan keadilan organisasi. 


\section{Kesimpulan dan Saran}

\subsection{Kesimpulan}

Berdasarkan penelitian yang telah dilakukan, maka kesimpulan yang dapat diberikan adalah:

1. Budaya organisasi berpengaruh positif terhadap komitmen organisasi. Hal ini dibuktikan dengan nilai signifikansi $0,013 / 2=0,0065<0,05$, sehingga hipotesis pertama yang mengatakan budaya organisasi berpengaruh positif terhadap komitmen organisasi diterima.

2. Budaya organisasi berpengaruh positif terhadap OCB. Hal ini dibuktikan dengan nilai signifikansi $0,000 / 2=0<0,05$, sehingga hipotesis kedua yang mengatakan budaya organisasi berpengaruh positif terhadap OCB diterima.

3. Komitmen organisasi berpengaruh positif terhadap OCB. Hal ini dibuktikan dengan nilai signifikansi $0,002 / 2=0,001<0,05$, sehingga hipotesis ketiga yang mengatakan komitmen organisasi berpengaruh positif terhadap OCB diterima.

4. Terdapat pengaruh komitmen organisasi sebagai variabel mediasi antara budaya organisasi dengan OCB. Hal ini dapat dibuktikan dengan nilai $\mathrm{Z}=2,64518627>1,98$, sehingga hipotesis keempat yang mengatakan terdapat pengaruh komitmen organisasi sebagai variabel mediasi antara budaya organisasi terhadap OCB diterima.

\subsection{Saran}

Berdasarkan penelitian yang telah dilakukan, maka saran yang dapat diberikan dalam penelitian ini adalah:

\section{Bagi Pimpinan BKAD Kabupaten Sleman}

Pimpinan perusahaan dapat meningkatkan OCB melalui implementasi variabel independen, yaitu budaya organisasi dan komitmen organisasi. Disarankan pimpinan harus mengutamakan komunikasi antara atasan dan bawahan dalam tujuan organisasi, serta pimpinan hendaknya memberi penghargaan yang baik untuk karyawannya yang sudah melakukan hal-hal baik dan berusaha ekstra melakukan pekerjaan, sehingga komitmen organisasi di dalam perusahaan meningkat.

\section{Bagi Peneliti Selanjutnya}

Bagi peneliti yang tertarik akan melakukan penelitian sejenis diharapkan untuk mengobservasi lebih jauh mengenai permasalahan yang terdapat pada Badan Keuangan dan Aset Daerah Kabupaten Sleman khususnya dan dapat menambahkan variabel lain yang dapat mempengaruhi OCB dengan variabel independennya yaitu komitmen organisasi, kepuasan, gaya kepemimpinan, dan budaya organisasi.

\section{Daftar Pustaka}

Amir, M. Taufiq. (2019). Perilaku Organisasi. Prenada Media.

Ardi, R. T. B., \& Sudarma, K. (2015). Pengaruh Persepsi Dukungan dan Keadilan Organisasi terhadap Organizational Citizenship Behavior dengan Komitmen Organisasional sebagai Variabel Intervening. Management Analysis Journal, 4(2), .

Ariani, Ayu Putu, Desak Ketut Sintaasih, \& Made Surya Putra. (2017). Pengaruh Budaya Organisasi terhadap Organizational Citizenship Behavior dengan Pemediasi Komitmen Afektif di Sekretariat Kabupaten Badung. E-Jurnal Ekonomi dan Bisnis Universitas Udayana. 6(7), 2665-2696.

Becker, G. S. (2002). Human Capital. The Concise Encyclopedia of Economics. 
Budiono, D. S. (2016). Pengaruh Budaya Organisasi terhadap Kinerja Karyawan melalui Komitmen Organisasi sebagai Variabel Intervening pada PT. Kerta Rajasa Raya. Jurnal Riset Ekonomi Dan Manajemen, 16(1), 29-43.

Dewi, N. L. P. Y. A., \& Suwandana, I. G. M. (2016). Pengaruh Kepuasan Kerja terhadap Organizational Citizenship Behavior dengan Komitmen Organisasi sebagai Variabel Mediasi. E-Jurnal Manajemen Unud, 5(9), 5643-5670 .

Emami, M., Alizadeh, Z., Nazari, K., \& Darvishi, S. (2012). Antecedents and Consequences of Organisational Citizenship Behaviour (OCB). Interdisciplinary Journal of Contemporary Research in Business, 3(9), 494-505.

Fasisca, Fuji \& Fahmy, Rahmi. (2018). Pengaruh Kepemimpinan Transformasional dan Budaya Organisasi terhadap Organizational Citizenship Behavior dengan Komitmen Organisasi sebagai Variabel Mediasi. Jurnal Ilmiah Mahasiswa Ekonomi Manajemen, 3(4), 175-190.

Fernandes, A. A. R. (2018). The Effect of Organization Culture and Technology On Motivation, Knowledge Asset and Knowledge Management. International journal of Law and Management, 60(5), 1087-1096.

Gilal, F. G., Zhang, J., Gilal, R. G., Gilal, R. G., \& Gilal, N. G. (2017). Supply Chain Management Practices and Product Development: A Moderated Mediation Model of Supply Chain Responsiveness, Organization Structure, Research and Development. Journal of Advanced Manufacturing Systems, 16(01), 35-56.

Ghozali, Imam. (2011). Aplikasi Analisis Multivariate Dengan Program IBM SPSS 10. Badan Penerbit Universitas Diponegoro.

Kalangi, R. (2015). Pengembangan Sumber Daya Manusia dan Kinerja Aparat Sipil Negara Di Kabupaten Kepulauan Sangihe Provinsi Sulawesi. Jurnal LPPM Bidang EkoSosBudKum, 2(1), 1-18.

Khan, S., \& Rashid, M. (2012). The Mediating Effect of Organizational Commitment in The Organizational Culture, Leadership and Organizational Justice Relationship with Organizational Citizenship Behavior: A Study of Academicians in Private Higher Learning Institutions in Malaysia. International Journal of Business and Social Science, 3(8), 83-91.

Kurniawan, A. (2015). Pengaruh Komitmen Organisasi terhadap Organizational Citizenship Behavior (OCB) PT X Bandung. Jurnal Manajemen Maranatha, 15(1), 95-118.

Lee, Y. H., Woo, B., \& Kim, Y. (2017). Transformational Leadership and Organizational Citizenship Behavior: Mediating Role of Affective Commitment. International Journal of Sports Science \& Coaching, 13(1), 373-382.

Lubis, M. S. (2015). Pengaruh Iklim Organisasi dan Komitmen Organisasi terhadap Pembentukan Organizational Citizenship Behavior (OCB) Karyawan dalam Rangka Peningkatan Kinerja. E-Jurnal Apresiasi Ekonomi, 3(2), 75-84.

Maulana, A. (2015). Pengaruh Organizational Justice terhadap Organizational Citizenship Behavior. Skripsi. UIN Sunan Gunung Djati Bandung. 
Prasasti, V. T., \& Yuniawan, A. (2017). Analisis Pengaruh Stres Kerja dan Lingkungan Kerja Non Fisik terhadap Organizational Citizenship Behavior (OCB) dengan Komitmen Organisasional sebagai Variabel Intervening. Diponegoro Journal of Management, 6(1), 304-317.

Pratiwi, I., \& Suharnomo, S. (2013). Analisis Pengaruh Budaya Organisasi dan Keadilan Organisasi terhadap Organizational Citizenship Behavior (OCB) dengan Komitmen Organisasional sebagai Variabel Intervening (Studi pada Karyawan Kantor PT Telekomunikasi Indonesia Tbk. Divisi Regional IV Wilayah Jateng dan DIY). Doctoral Dissertation, Fakultas Ekonomika dan Bisnis.

Rosyada, N. F., \& Rahadjo, M. (2016). Pengaruh Budaya Organisasi dan Komitmen Organisasi terhadap Organizational Citizenship Behavior (OCB) Pegawai di Kanwil PT. Pegadaian (Persero) Jawa Tengah. Diponegoro Journal Of Management, 5(3), 1143-1154.

Sari, T. K. (2013). Pengaruh Budaya Organisasi terhadap Komitmen Organisasi melalui Kepuasan Kerja Karyawan. Jurnal Ilmu Manajemen (JIM), 1(3), 827-836.

Sari, M. K., dan Hajriani, I. (2015). Pengaruh Karakteristik Budaya Organisasi terhadap Organizational Citizenship Behavior. Journal of Economic and Economic Education, 3(2), 234-242.

Sari, I. G. A. D. I., \& Dwirandra, A. A. N. B. (2019). The Ability of Organization Commitment and Moderate Worked Motivation By The Effect of Budget Goal Clarity In Budgetary Inaccuracy. International Research Journal of Management, IT and Social Sciences, 6(3), 1117.

Sisca, S., Simarmata, H. M. P., Grace, E., Purba, B., Dewi, I. K., Silalahi, M., \& Sudarmanto, E. (2021). Manajemen Inovasi. Yayasan Kita Menulis.

Sugiyono. (2014). Metode Penelitian Kuantitatif, Kualitatif dan R\&D. Penerbit Alfabeta.

Sumanto, S., \& Herminingsih, A. (2016). Pengaruh Budaya Organisasi Dan Motivasi Kerja Terhadap Komitmen Organisasional Pada PT. Bank Central Asia, Tbk. Kantor Cabang Utama Tangerang. Jurnal Ilmiah Manajemen dan Bisnis Mercu Buana, 2(1), 96-110.

Tannady, H., \& Sitorus, T. (2017). Role of Compensation, Organization Culture, And Leadership On Working Motivation of Faculty Member (Study Case: Universities In North Jakarta). IOSR Journal of Business and Management, 19(10), 41-47.

Wibowo. (2012). Manajemen Kinerja. Edisi Ketiga. Rajawali Pers.

Widiyanto, Joko. (2010). SPSS for Windows Untuk Analisis Data Statistik dan Penelitian. BP-FKIP Universitas Muhammadiyah Surakarta.

Wombacher, J. C., \& Felfe, J. (2017). Dual Commitment In The Organization: Effects of The Interplay of Team And Organizational Commitment On Employee Citizenship Behavior, Efficacy Beliefs, And Turnover Intentions. Journal of Vocational Behavior, 102, 1-14.

Yulianti, D. (2014). Analisis Lingkungan Internal Dan Eksternal dalam Pencapaian Tujuan Perusahaan. Jurnal Sosiologi, 16(2), 103-114.

Andira Ramadha Arundita et al., (Pengaruh Budaya Organisasi terhadap Organizational

Citizenship Behavior dengan Komitmen Organisasi sebagai Variabel Mediasi) 